\title{
Participative HR-Technologies in the Governance of the Russian Regions
}

\author{
Svetlana E. Martynova ${ }^{+*}$ and Svetlana A. Evarovich ${ }^{\dagger}$
}

\begin{abstract}
The modern reforms in the governance are connected with the development of the participative interaction of the administration with the citizens, implying the involvement of the society into the processes of elaboration and implementation of the managerial decisions. The objective of the research is the analysis of the current HR-technologies application practice in the governance of the Russian regions from the perspective of compliance with the participativity principle. As the theoretic base for the achievement of the objective, the authors considered: the notion of participativity in the technological sense - from the perspective of the mechanisms and algorithms of co-management; the notion of competency framework as a base for the development and implementation of HR-technologies, including those of the participative nature. The authors applied the following methods of research: analysis of documents, interviews with the public officials managing the processes of the competency framework formation. As part of the research, the authors considered the HR-technologies of eight territorial entities of the Russian Federation. It has been found that the participative mechanisms implying active participation of the population in the adoption of the HR-related decisions are not enough yet. It is more common to bring expertise only representing the opinion of the professional community and often among the public official themselves. However, the participative practice is gradually being developed, and the prerequisites for the use of a wider range of tools approbated in other managerial technologies are being formed. Besides, the practice of particular regions of the RF already shows not just the participation of the society in the adoption of the HR-related decisions, but its direct and ultimate influence on them.
\end{abstract}

Keywords: Postindustrial society, 'Service' State, HR-technologies, Participativity, Competency Framework.

\footnotetext{
${ }^{\dagger}$ Department of Public Governance, Tomsk State University, 634050, 36 Lenin Ave, Tomsk, Russian Federation,

*Corresponding Author, email: status.sm@mail.ru

C2018Martynova and Evarovich. This is an Open Access article distributed under the terms of the Creative Commons Attribution License (http://creativecommons.org/licenses/by/2.0), which permits unrestricted use, distribution, and reproduction in any medium, provided the original work is properly cited.
} 


\section{Introduction}

Since 2005, the concepts and decrees of the government are focused on the creation of effective channels of public influence on the preparation and adoption of the decisions by the executive authorities (Government of the Russian Federation, 2005; Government of the Russian Federation, 2014; Ministry of Economic Development of the Russian Federation, 2018). Participativity is declared by the new principle and the HR-policy of the executive bodies (President of the Russian Federation, 2012).

The relevance of the participativity principle development in the HR-policy has predetermined the objective of this research. We defined the objective as follows: the analysis of the current practice of the HRtechnologies application in the governance of the Russian regions from the perspective of compliance with the participativity principle.

Participativity of the modern administration as the leading principle of decision-making is described rather comprehensively (Speer, 2012; Gonzalez et al., 2013; Kirillov, 2013; Lepsky, 2015; Casula, 2015; Dommett and Flinders, 2015; Witesman and Walters, 2015; Urzha, 2015; Qvist, 2016; Bondaletov, 2016; Buley et al., 2016; Vinichenko et al., 2016; Simonin et al., 2016; Buley et al., 2016; Kirillov et al., 2017; Silagadze, 2017; Akhmetshin et al., 2018). However, ensuring the participation of the society in the recruitment of the candidates for the public service, one may observe the deficiency of scientific elaboration. It explains the novelty of our research.

At the creation of the basic algorithm of the participative HR-technology, the authors are based on the algorithm of the participative 'service' governance of social technology (Martynova et al., 2017). The algorithm may be represented as several stages:

- Stage 1 - revealing of the social need;

- Stage 2 - documenting of the expectations as a standard upon discussing with the citizens the final variant of the governing document;
- Stage 3 - recruitment of the officials by the standard;

- Stage 4 - an estimate of the citizens' level of satisfaction by the implementation of the standard.

The scientists pay attention to the problem of the frameworks clustering, and the definition of the methods for evaluation of the personnel based on them (Panova and Barinov, 2014; Lapygin and Yerashova, 2013), but not to the technology of the competency framework formation in the public service.

\section{Materials and Methods}

The authors present the participative algorithm of the public official's competency framework formation and implementation as follows:

- Stage 1 - revealing of the public expectations connected with the characteristics of the public official through consulting, surveying, etc.

- Stage 2 - formation of competency framework: list and definitions, implemented through the crowdsourcing provided that the citizens will be acquainted with the analysis results obtained at the first stage. The discussion of the final variant takes place publicly, including the blogs, websites, chats, social media, and forums.

- Stage 3 - the recruitment based on the competency framework. It implies the participation in the activities of the tender and certification committees of the citizens, which at least evaluate the compliance of the recruitment procedure (tender tasks and the results of the recruitment) with the goal of revealing of the socially significant competencies documented in the framework.

- Stage 4-evaluation of the citizens' level of satisfaction with the activities of the public officials recruited on the bases of the stated competency framework is implemented through the surveying, including via the internet, and the analysis of the public appeal. 
To achieve the objective of the research, the following methods were defined: document analysis; interview with public officials, managing the competency framework formation process.

The focus of the research embraced the regions marked at the federal level during the tenders held by the RF Ministry of Labor 'The Best HRPractices of the Public Service' in 2015-2016 as part of the application of the competency approach. Among them are the Tomsk, Yaroslavl, Ulyanovsk, Voronezh oblasts, Moscow, Khanty-Mansijsk Autonomous District, and Komi Republic (Ministry of Labor and Social Protection of the Russian Federation, 2016a; Ministry of Labor and Social Protection of the Russian Federation, 2017a).

The research of the practice in the Tomsk Oblast takes the central position due to the special status of this territory and the significant experience in the use of the competency framework for the tasks of governance. So, the attributes of the postindustrial sociality in the Tomsk Oblast are confirmed by the following data:

- In 2016, the region took the fourth position in the rating of the innovative development among the RF entities (Association of Innovative Regions of Russia, 2017);

- It takes the leading position according to the rating of the population's initiative (POF database, 2010).

- In 2014, it became the best region of Russia in the development of the small and middle-sized business (Administration of Tomsk Region, 2015).

\section{Results}

Since 2012, the government of Moscow has developed and applied the corporate competency framework of a new type of official (Sarkisov, 2014). This framework is the decision-making basis for the vacancy filling and the evaluation of the public official's effectiveness. For the evaluation, the authors apply the technology of the 'Evaluation Center', which is conducted with the attraction of both the internal and external experts. The analysis of the sociological projects implemented in Moscow since 2009 regarding the problem of the 'ideal' image of the public official has revealed some differences compared with the applied competency framework (Rabinovich, 2013).

Since 2014, in the Yaroslavl Oblast, the methods for evaluation of the basic and special competencies of the public officials have been introduced. The methods imply the active involvement of the expert community in the process of correction of the competency framework and the evaluation procedures, as well as the participation in the evaluation itself. The participative mechanisms are questionnaires, discussion at the meetings of the Council of Independent Experts, and participation of the experts in the work of the evaluation committees.

The next region is the Khanty-Mansijsk Autonomous District. This is the region where the competency framework is used for certification of the public officials, which is not popular among the Russian regions. Since 2014, such methods for certification of the public officials in the city of Yugorsk are used, where they are evaluated by the competency framework consisting of 15 positions (Ministry of Labor and Social Protection of the Russian Federation, 2017b). The analysis of the framework allows suggesting that its basis is laid by the methodical recommendations of the recruitment developed by the Ministry of Labor and Social Protection of the Russian Federation (2013).

In this region, they actively use the participative mechanisms in the HR-technologies at the public service. Since 2011, the candidates for the leading positions of the industrial subdivisions have been publicly discussed. The applicants participating in the tender propose their election agendas posted on the website of the Administration for the internet voting (Khanty-Mansijsk Autonomous Area - Yugra, 2018). The next stage of the recruitment is the defence of the agendas in front of the professional community at the conferences. 
The governor makes the final decision according to the results of the conference.

Similar participative mechanisms, implying mass participation of the population, are revealed in the HR-technologies in the Tula Oblast. In 2013, in this region the project 'People's Government was the Candidate Pool' was launched. The objective of this project is the formation of the search system for the talented managers into the candidate pool for filling the leading positions in the executive authorities of the Tula Oblast through the open tender. Each resident of the Tula Oblast may fill out the application to the candidate pool and participate in the tender. Upon completion of the application receipt at the internet portal 'Open Region 71' (2018), the voting for the candidates takes place. The winner will be the candidate with the highest rating.

In the Ulyanovsk Oblast, in 2016 they adopted the 'Strategy of the HR-technologies Development in the Public Administration up to 2030', the goal of which was the formation of the new type of public official based on the principle of meritocracy (Ministry of Labor and Social Protection of the Russian Federation, 2017a). As part of the strategy, they planned the development of the competency framework for the public service positions; and the methods for evaluation of public officials. This document was submitted to the competition 'The Best HR-Practices in the Public Service' in 2016, so one may suggest that the 'Methodical Tools form the basis at the development of the competency framework in the Ulyanovsk Oblast for Scheduling the Recruitment of the Candidates for Filling the Public Positions' of the Ministry of Labor and Social Protection of the Russian Federation (2016b).

In the Voronezh Oblast, since 2013, they have been integrating the Public Authorities Efficiency Management System, one of the elements of which is the competency framework of the senior executives of the regional public service. They developed the corporate competency framework consisting of nine competencies and the matrix of the competencies evaluated by the managerial levels (Ministry of Labor and Social Protection of the Russian Federation, 2017a). The framework includes the following competencies: public service, team player, building relationships and influence, the aspiration to the achievement of the large-scale goals, personal maturity, team leader, building efficient work processes, efficient reasoning, creative approach, and readiness to personal development.

There is the Council on HR-Policy at the Governor of the Voronezh Oblast, consisting of the representatives of the regional legislative body, and the representatives of the public organisations. Except for the analysis of the legislative practice regarding the issues of public service and introduction of the proposals on the improvement of these activities, the Council is authorised to prepare the conferences and seminars on the generalisation and distribution of the best HR-practices.

A rather significant is the experience of the Komi Republic. In 2014, the Decree of the republican government approved the 'HRPolicy in the System of Governance of the Komi Republic' State Program. Among the indicators and parameters of the Program, there are:

the confidence index to the public officials of the Komi Republic (\% of the total number of respondents);

the share of the public authorities of the Komi Republic, applying the competency approach at the conduction of the tenders, certifications, qualification exams of the total number of the self-governing authorities (Ministry of Labor and Social Protection of the Russian Federation, 2017a).

Next, this is the analysis of the Tomsk Oblast, in the conduction of which the authors took a direct part. The practice of the public official's competency framework formation was started here as early as in 2007 as part of the project of the formation and preparation of the regional candidate pool. The stages of the algorithm of the competency framework creation and application were: 
- development of the project framework by the scientists;

- discussion of the initial variant at the focus-groups with the involvement of public officials, people in business, and scientific experts through the surveying;

- formation of the competency framework final variant;

- use of the framework at the recruitment to the managerial candidate pool of the region and for the creation of the educational program.

Thus, the participative mechanisms were qualitative and quantitative surveys, however not including the analysis of the public opinion. This gap was eliminated in 2009-2012 as part of the project on the candidate pool formation and development for the positions of the public leaders and their deputies. The stages of the algorithm of the creation and use of the public leaders' competency frameworks were the following:

- revealing of the public expectations connected with the personality and activities of the public leaders during the surveying in all the municipalities of the Tomsk Oblast (the surveying was conducted through the personal 'face-toface' interview, the sampling of each of the 20 municipalities was composed the way to limit the data precision by $4 \%$, the total number of respondents was 11800 people);

- analysis of the normative documents containing the requirements towards the public officials;

- competency framework formation based on the result of the research conducted through these two methods;

- use of the framework at the recruitment to the managerial candidate pool of the public authorities and to create the educational program for the persons included into the pool.

In 2013-2014, a significant effect on the public official's competency framework application practice in the Tomsk Oblast was taken by the 'Methodical Tools on Imposition of the
Qualified Requirements towards the Public Service Positions' of the Ministry of Labor and Social Protection of the Russian Federation (2013), adopted for the discussion in the Administration of the Tomsk Oblast. These tools included the list of the professional and personal characteristics and the corresponding professional skills. Notably, there is no notion of 'competency' and 'competency framework' in this document.

In general, there are the following professional qualities recommended in the system of public service: enhancement of the authority of the public officials; effective interpersonal communication, relevant style of communication; and the focus on achievement of the result.

Among the applied professional qualities there are the following: gathering and analysis of the information; qualitative preparation of the documents in compliance with the requirements; focus on protection of the citizens' lawful interests; self-development; transfer of knowledge and experience (mentorship); persuasive communication; work in team; creative and innovation-based approach.

The process of the new competency framework development has been initiated in the Tomsk Oblast:

- formation of the list of competencies for the categories and groups of positions (set of relevant characteristics required for effective performance of the duties) (Administration of the Tomsk Region, 2014);

- development of the framework of the professional qualities necessary for filling the positions of public service including general professional qualities applied professional qualities and professional managerial qualities;

- definition of the competency profiles for the categories and groups of positions based on the expert evaluation; the improvement of the competencies evaluation system by the categories and groups of positions (selection of the 
methods and procedures to define the level of development of some or other competencies).

The changes (compared with the situation of 2009-2012) undergone by the public official's competency framework formation technology is shown by the interview with the deputy director of the regional Public Service Department - the governing body of the Tomsk Oblast. When describing the stages of the algorithm of the framework modelling, the respondent listed as follows:

- study of the Methodic Tools of the RF Ministry of Labor;

- creation of the workgroup on the competency framework formation. The workgroup includes the representatives of the scientific community (one-third of the group participants), who earlier took part in the projects of the regional administration, and the employees of the public service department. The invited experts are called to correct the formulated qualification characteristics offered by the Methodic Tools;

- the expert evaluation of the competency contents from the perspective of the description of the behavioural indicators by the members of the workgroup;

- The choice from the offered list and elaboration of the competency contents, their clustering; ranging from the competencies from 1 to 10 points according to their significance. Ten characteristics were selected, among which there were universal and special ones. The process of discussing the competency frameworks included the employees of the public executive authorities, 1015 people in total. The public officials implemented the choice of the significant competencies for the corresponding group of positions through the ranging method.

Thus, the algorithm of the public official's competency framework formation developed for four groups of positions implied the analysis of the variants and mechanism of the public officials' surveying proposed by the Ministry of Labor.

In 2016, the RF President issued a decree 'Concerning the Main Directions of the Public Service Development in the Russian Federation for the Period of 2016 - 2018', which as the measures and events for the increase in the objectiveness and transparency of the tender procedures to fill the vacancies in the public service and inclusion to the candidate pool of the state authorities contain a task to incorporate the single methods of holding the tenders up to 2018 (President of the Russian Federation, 2016).

The new 'Tools for Scheduling the Recruitment to fill the Vacancies in the Public Service' prepared by the RF Ministry of Labor implies the corrected variant of the professional skills and their indicators. Besides, it includes the parameters of the issues for conducting the competency interview according to the suggested list of the professional traits and other methods for the evaluation (Ministry of Labor and Social Protection of the Russian Federation, 2016b).

Thus, in the HR-technologies of the RF, one may observe two following tendencies: on the one hand, at the federal level of the legislative activities, there is an aspiration to the singularity of the methods for the recruitment to the public service. On the other hand, as part of the tenders for the best HR-policies held by the RF Ministry of Labor, the more entities propose their experience in the incorporation of the competency approach.

The presence of participative mechanisms exactly in the technology of the competency framework formation and use is shown by the experience of the Tomsk and Yaroslavl oblasts (Table 1).

Participative mechanisms are the surveying of the population, including through the internettechnologies, expert evaluation (Table 2 ). 


\begin{tabular}{|c|c|c|}
\hline Region & $\begin{array}{l}\text { Presence of Participative } \\
\text { Mechanisms in the HR- } \\
\text { Technologies in general }\end{array}$ & $\begin{array}{l}\text { Presence of Participative Mechanisms exactly } \\
\text { in the Technology of the Competency } \\
\text { Framework Formation in case the Framework } \\
\text { is being developed }\end{array}$ \\
\hline Moscow & $\begin{array}{l}\text { Only the competency } \\
\text { framework formation } \\
\text { technology has been } \\
\text { revealed }\end{array}$ & No, no competency framework is developed \\
\hline Tomsk Oblast & $\begin{array}{l}\text { Only the competency } \\
\text { framework formation } \\
\text { technology has been } \\
\text { revealed }\end{array}$ & $\begin{array}{l}\text { Yes (in 2009-2012) } \\
\text { No (since 2013), no competency framework is } \\
\text { developed }\end{array}$ \\
\hline Tula Oblast & Yes & The competency framework is not developed \\
\hline $\begin{array}{l}\text { Khanty-Mansijsk } \\
\text { Autonomous } \\
\text { District }\end{array}$ & Yes & $\begin{array}{l}\text { No, no competency framework is developed } \\
\text { (the same as the methodic tools of the RF } \\
\text { Ministry of Labor) }\end{array}$ \\
\hline Yaroslavl Oblast & $\begin{array}{l}\text { Only the competency } \\
\text { framework formation } \\
\text { technology has been } \\
\text { revealed }\end{array}$ & $\begin{array}{l}\text { Yes (but only with the participation of experts, } \\
\text { not of the society in general) }\end{array}$ \\
\hline Voronezh Oblast & Yes & $\begin{array}{l}\text { The competency framework is being } \\
\text { developed; the mechanism is not described }\end{array}$ \\
\hline Ulyanovsk Oblast & Yes & $\begin{array}{l}\text { The competency framework is being } \\
\text { developed; the mechanism is not described }\end{array}$ \\
\hline Komi Republic & Yes & Yes \\
\hline
\end{tabular}

\begin{tabular}{|c|c|}
\hline Region & Types of Participative Mechanisms in the HR-Technologies \\
\hline Moscow & Expert evaluation \\
\hline Tomsk Oblast & Surveying of the population, expert evaluation \\
\hline Tula Oblast & $\begin{array}{l}\text { Participation of the citizens as the candidates for the candidate pool, } \\
\text { internet-surveying of the population }\end{array}$ \\
\hline $\begin{array}{l}\text { Khanty-Mansijsk } \\
\text { Autonomous District }\end{array}$ & $\begin{array}{l}\text { Internet-surveying of the population, evaluation of the professional } \\
\text { community }\end{array}$ \\
\hline Yaroslavl Oblast & $\begin{array}{l}\text { Questionnaires, discussions at the meetings of the expert council, and } \\
\text { participation of the experts in the activities of the evaluation } \\
\text { committees }\end{array}$ \\
\hline Voronezh Oblast & Discussion at the HR-Policy Council \\
\hline Ulyanovsk Oblast & Not revealed \\
\hline Komi Republic & Independent surveying of the population \\
\hline \multicolumn{2}{|c|}{ Source: Compiled by the authors } \\
\hline
\end{tabular}

Among the stages of the participative have revealed only one stage, implying the algorithms of the public official's competency participation of the citizens - the definition of framework formation and use, the authors the public expectations (Table 3 ). 
Table 3: Presence of the Stages of the Participative Algorithms of the Public Official's Competency Framework Formation (in the regions, where the competency framework formation technology is applied)

\begin{tabular}{|l|l|l|l|l|}
\hline $\begin{array}{l}\text { Stages of the Participative } \\
\text { Algorithms of the Public } \\
\text { Official's Competency } \\
\text { Framework Formation and Use }\end{array}$ & Moscow & $\begin{array}{l}\text { Tomsk } \\
\text { Oblast }\end{array}$ & $\begin{array}{l}\text { Yaroslavl } \\
\text { Oblast }\end{array}$ & Komi Republic \\
\hline $\begin{array}{l}\text { Definition of the public } \\
\text { expectations }\end{array}$ & $\begin{array}{l}\text { Not } \\
\text { revealed }\end{array}$ & Yes & Not revealed & Not revealed \\
\hline $\begin{array}{l}\text { Competency framework } \\
\text { formation with the participation } \\
\text { of the citizens }\end{array}$ & $\begin{array}{l}\text { Not } \\
\text { revealed }\end{array}$ & $\begin{array}{l}\text { No (only with } \\
\text { the } \\
\text { participation } \\
\text { of experts) }\end{array}$ & $\begin{array}{l}\text { No (only with } \\
\text { the } \\
\text { participation } \\
\text { of experts) }\end{array}$ & Not revealed \\
\hline $\begin{array}{l}\text { Recruitment of the candidates } \\
\text { based on the competency } \\
\text { framework with the } \\
\text { participation of the citizens }\end{array}$ & $\begin{array}{l}\text { No (only } \\
\text { with the } \\
\text { participation } \\
\text { of experts) }\end{array}$ & $\begin{array}{l}\text { No (only with } \\
\text { the } \\
\text { participation } \\
\text { of experts) }\end{array}$ & $\begin{array}{l}\text { No (only with } \\
\text { the } \\
\text { participation } \\
\text { of experts) }\end{array}$ & Not revealed \\
\hline $\begin{array}{l}\text { Evaluation of the citizen's level } \\
\text { of satisfaction with the activities } \\
\text { of the public officials recruited } \\
\text { on the basis of the competency } \\
\text { framework }\end{array}$ & $\begin{array}{l}\text { Not } \\
\text { revealed }\end{array}$ & No & Not revealed & $\begin{array}{l}\text { Yes } \\
\text { (independent } \\
\text { surveying of } \\
\text { the }\end{array}$ \\
\hline Source: Compiled & population) \\
\hline
\end{tabular}

Source: Compiled by the authors

\section{Discussion}

The regular involvement of the experts in the HR-activities of the administration cannot be deemed as the full-fledged implementation of the participativity principle. The experts are not to the full extent the representatives of the population in general and mostly express their opinions from the professional rather than from the socially significant positions. The involvement of the individuals who would be typical consumers of the public services and could evaluate the activities of the public officials from the perspective of a citizen as part of the 'service' framework is not observed. Moreover, when the public officials become the experts themselves, it even contradicts to the principles of the modern governance concept.

The technology of the public official's competency framework formation and use is implemented not in each region. Presence of the participative mechanisms exactly in this technology shows the experience of two regions (Tomsk and Yaroslavl oblasts); in addition to that one of the regions practices only the participation of experts.

The full-fledged participative algorithm with the mechanisms of involvement of the society at each stage of the competency framework development and implementation has been revealed in no region. However, there are the examples of such full-fledged manifestation at particular stages - for example, revealing of the public expectations connected with the personality and activities of the municipal leaders in the course of the surveying among all the municipalities (Tomsk Oblast).

There is no direct correlation between the society's environment and the managerial technologies in the region. We have not revealed the public official's competency framework development. To our mind, it encourages to reconsider the purpose of the framework under conditions of participative management. If the society takes part in the HR-technologies at all the stages: from the recruitment to the evaluation of the candidates' activities - thus, it directly expresses its opinion on the nature of the 
public official's competencies necessary for the society. The need of the competency framework may arise in the cases when this tool replaces the direct expression of personal preferences, so to speak, represents on behalf of the society. In the conditions of comanagement, maybe, the participative algorithm of the competency framework formation and use itself will be amended: both from the perspective of the purpose for the competency framework formation, and from the perspective of the stages which may be reduced.

It has been stated that the transfer in the regions from the competency framework to the other participative HR-technologies allows not contradicting to the industrial recommendations (regarding only the competency framework) and at the same time developing the participation of the society in the management.

\section{Conclusions}

The current practice of the HR-technologies application in the governance of the Russian regions has shown that the participative mechanisms, implying mass participation of the population in the HR decision-making processes are still not sufficient. The same conclusion can also be made regarding the participative mechanisms in the technology of the public official's competency framework formation and use. Thus, HR-technologies of the Russian regional administrations still not comply with the attributes of the postindustrial sociality.

The introduction of the participative HRtechnologies may be considered as an innovative process. The regulatory base, which the administration of the RF regions should use as guidance, has been formed since 2005. Though the particular participative mechanisms (surveying) have been acquired, which allow involving the society to the HR decision-making processes, and the prerequisites are being formed for the use of a wider range of tools approbated in the other managerial technologies. Besides, the practice of the particular Russian regions shows already not just the participation of the society in the HR decision-making processes, but its direct and ultimate influence on these decisions.

The development of the participative HRtechnologies in the regional administrations is not directly connected with the level of the social development in these territories, but rather depends on the degree of awareness of the need in the transformation of the technologies by the authorised person responsible for the HR-policy.

The implementation of the participative principle of the decision-making encourages reconsidering the public official's competency framework application area. In the case when the society directly expresses its opinion on the necessary public official's competencies due to its evaluation, the need for the competency framework formation may be doubtful. At least, the reasonability of the competency framework is not apparent in the HR decisions about the leading positions.

\section{References}

Administration of the Tomsk Region. (2014). Decree of July 16, 2014 N 442-ra "On Approval of the Main Directions of the Development of Human Resources Technologies in the State Civil Service of the Tomsk Region and Measures to Develop and Introduce New Personnel Technologies in the State Civil Service of the Tomsk Region for 2014-2016". Available at http://docs.cntd.ru/document/46791528 3

Administration of Tomsk region. (2015). Small and Medium Businesses. Available at https://tomsk.gov.ru/Maliy-i-sredniybiznes

Akhmetshin, E. M., Sharafutdinov, R. I., Gerasimov, V. O., Dmitrieva, I. S., Puryaev, A. S., Ivanov, E. A., Miheeva, N. M. (2018). Research of human capital and its potential management on the example of regions of the Russian Federation. Journal of Entrepreneurship Education, 21(2), pp. 1-14. 
Association of Innovative Regions of Russia. (2017). Rating of Innovative Regions of Russia: Version 2016. Available at http://www.iregions.org/images/files/presentations/AI RR_26.12.pdf

Bondaletov, V.V. (2016). Forms of public selforganization of citizens and their participation in municipal government: legal analysis. Materials of the Afanasiev Readings, 1(14), pp. 56-64.

Buley, N.V., Demchenko, T.S., Makushkin, S.A., Vinichenko, M.V., Melnichuk, A.V. (2016). Human resource management in the context of the Global economic crisis. International Journal of Economics and Financial Issues, 6(S8), pp. 160-165.

Buley, N.V., Demchenko, T.S., Makushkin, S.A., Vinichenko, M.V., Melnichuk, A.V. (2016). Human resource management in the context of the global economic crisis. International Journal of Economics and Financial Issues, 6(S8), pp. 160-165.

Casula, M. (2015). Opportunity Structures for Citizens' Participation in Italian Regions: A Case Study, Journal of Public Deliberation, 11(2), Article 6. Available at http://www.publicdeliberation.net/jpd/v ol11/iss2/art6

Dommett, K., Flinders, M. (2015). The Centre Strikes Back: Meta-Governance, Delegation, and the Core Executive in the United Kingdom, 2010-14, Public Administration, 93(1), pp. 1-16.

Gonzalez, R., Llopis, J., Gasco, J. (2013). Innovation in Public Services: The Case of Spanish Local Government, Journal of Business Research, 66(10), pp. 2024-2033.

Government of the Russian Federation. (2005). Order of October 25, $2005 \mathrm{~N}$ 1789-r "The Concept of Administrative Reform in the Russian Federation in 20062010". Available at http://pravo.gov.ru/proxy/ips/?docbody= \&nd $=102100675$
Government of the Russian Federation. (2014). Order of January 30, 2014 N 93-r "The concept of openness of federal executive bodies". Available at http://pravo.gov.ru/proxy/ips/?docbody= \&nd $=102171010$

Khanty-Mansijsk Autonomous Area - Yugra. (2018). Polls and Votes. Available at http://www.admhmao.ru/votes/

Kirillov, A.V. (2013). Ways to improve the efficiency of selection of management personnel. Materials of the Afanasiev Readings, 1(11), pp. 126-131.

Kirillov, A.V., Ushakov, D.S., Vinichenko, M.V., Makuchkin, S.A., Melnichuk, A.V. (2017). Career opportunities for the management's personnel reserve. Eurasian Journal of Analytical Chemistry, 12(A Multidisciplinary Approach to science 5b), pp. 723-733.

Lapygin, Yu.N., Erashova, O.V. (2013). Models of Competences of State Civil Servants, Modern Economy: Problems, Trends, Prospects, 9, pp. 189-208.

Lepsky, V.E. (2015). Evolution of Ideas about Management (Methodological and Philosophical Analysis). Moscow: KogitoCenter.

Martynova, S.E., Dmitriev, Yu.G., Gajfullina, M.M., Totskaya, Yu.A. (2017). "Service" Municipal Administration as Part of the Development of Youth Entrepreneurship in Russia. Social Indicators Research, 133(3), pp. 1151-1164.

Ministry of Economic Development of the Russian Federation. (2018). Assistance in the development of civil society institutions. Available at http://economy.gov.ru/minec/activity/se ctions/admReform/publicsociety/

Ministry of Labor and Social Protection of the Russian Federation. (2013). Methodical Tools for Establishment Qualification Requirements for Civil Service Positions. Available at http://docplayer.ru/33463060- 
Metodicheskiy-instrumentariy-poustanovleniyu-kvalifikacionnyhtrebovaniy-k-dolzhnostyamgosudarstvennoy-grazhdanskoysluzhby.html

Ministry of Labor and Social Protection of the Russian Federation. (2016a). Database "The Best HR-Practices of the Public Service" (2015). Available at https://rosmintrud.ru/ministry/program ms/gossluzhba/14

Ministry of Labor and Social Protection of the Russian Federation. (2016b). Methodical Tools for Scheduling the Recruitment of the Candidates for Filling the Public Positions. Available at https://rosmintrud.ru/ministry/program ms/gossluzhba/16/2

Ministry of Labor and Social Protection of the Russian Federation. (2017a). Database "The Best HR-Practices of the Public Service" (2016). Available at http://www.rosmintrud.ru/ministry/prog ramms/gossluzhba/17/base/2016

Ministry of Labor and Social Protection of the Russian Federation. (2017b). Database "Best HR practices in the system of state and municipal management" (20152017).

Available at https://rosmintrud.ru/ministry/program $\mathrm{ms} /$ gossluzhba/17/1

Open Region 71. (2018). Useful City Services. Available at https://or71.ru/

Panova, E.A., Barinov, D.A. (2014). Competence Approach in the Civil Service Management System. Public Administration, Electronic Bulletin, 45, pp. 36-57.

POF Database. (2010). Public Opinion Foundation at the XIII Tomsk Innovation Forum INNOVUS-2010. Available at http://bd.fom.ru/report/map/fomterri/fo mterry_pressr/fomter250510_pressr

President of the Russian Federation. (2012). Decree of May 7, 2012 N 601 "On the main directions of improving the system of public administration." Available at http://pravo.gov.ru/proxy/ips/?docbody= \&nd $=102156335$

President of the Russian Federation. (2016). Decree of August 11, 2016 N 403 "On the Main Directions of Development of the State Civil Service of the Russian Federation for 2016-2018". Available at http://pravo.gov.ru/proxy/ips/?docbody= \&nd=102406096

Qvist, M. 2016. Activation Reform and InterAgency Co-Operation - Local Consequences of Mixed Modes of Governance in Sweden, Social Policy \& Administration, 50(1), pp. 19-38.

Rabinovich, P.V. (2013). Personnel Policy of the City of Moscow: Requirements for a Modern Civil Servant, Theory and practice of social development, 8, pp. 83-85.

Sarkisov, G. (2014). An Official of a New Type: A Model of Competences. Available at http://mguu.ru/chinovnik-novogo-tipamodel-kompetentsij/

Silagadze, A. (2017). "Post-Soviet paradoxes" of unemployment rate. Bulletin of the Georgian National Academy of Sciences, 11(1), pp. 136-141.

Simonin, P.V., Sokolova, A.P., Bogacheva, T.V., Alexeenko, V.B., Vetrova, E.A. (2016). Institutionalization of conflict and compromise solutions and social and labor relations in higher educational institutions. Indian Journal of Science and Technology, 9(19), pp. 1-14.

Speer, J. (2012). Participatory Governance Reform: A Good Strategy for Increasing Government Responsiveness and Improving Public Services? World Development, 40(12), pp. 2379-2398.

Urzha, O.A. (2015). Formation of the personnel policy at the municipal level: problems and solutions. Materials of the Afanasiev Readings, 1(13), pp. 83-87.

Vinichenko, M.V., Frolova, E.V., Kabanova, E.E., Kozyrev, M.S., Evstratova, T.A. (2016). The youth employment problems. Journal 
of Advanced Research in Law and Acknowledgements

Economics, 7(2), pp. 378-387.

This study was supported by The Tomsk State

Witesman, E.M., Walters, L.C. 2015. Modeling University competitiveness improvement

Public Decision Preferences Using program.

Context-Specific Value Hierarchies,

American Review of Public

Administration, 45(1), pp. 86-105. 